\title{
Modulation of oxidative stress by enalapril and valsartan in adrenaline treated rats: a comparative study
}

\author{
Huda $\mathrm{S}^{1}$, Akhter $\mathrm{N}^{2}$ \\ ${ }^{1}$ Department of Pharmacology, Bangladesh Medical College, Dhanmondi, Dhaka, ${ }^{2}$ Department of \\ Pharmacology, Bangabandhu Sheikh Mujib Medical University, Shahbag, Dhaka. \\ Email: sharmila_huda@yahoo.com
}

\begin{abstract}
Angiotensin (Ang II) II is known to promote oxidative stress in acute myocardial infarction (AMI). Inhibition of renin angiotensin system (RAS) or blockade of Ang II receptors may therefore be effective in reducing oxidative stress during AMI. The study evaluates and compares the protective effect of Angiotensin Converting Enzyme (ACE) inhibitor and $\mathrm{AT}_{1}$ receptor blocker in adrenaline induced oxidative stress in rats. Rats were treated with two successive injections of adrenaline subcutaneously at a dose of $2 \mathrm{mg} / \mathrm{kg}$ administered 24 hours apart. In other two groups of rats enalapril $(30 \mathrm{mg} / \mathrm{kg}$ ) or valsartan $(30 \mathrm{mg} / \mathrm{kg}$ ) were given orally once daily through intragastric tube for 2 weeks and then two injections of adrenaline were administered 24 hours apart. Serum Aspertate Transaminase (AST), plasma Malonde Aldehyde (MDA), erythrocyte GSH and serum vitamin E levels were measured 24 hours after the $2^{\text {nd }}$ injection of adrenaline in all the groups. Administration of adrenaline caused significant increase $(\mathrm{p}<0.001)$ in serum AST and plasma MDA levels and decrease $(\mathrm{p}<0.001)$ in erythrocyte GSH and serum vitamin E levels. Pre-treatment of enalapril or valsartan for 14 days reduced $(\mathrm{p}<0.001)$ serum AST and plasma MDA levels and increased the concentration of erythrocyte GSH in enalapril pre-treated group $(\mathrm{p}<0.01)$ and in valsartan pre-treated group $(\mathrm{p}<0.05)$. Pre-treatment of enalapril or valsartan also increased $(\mathrm{p}<0.01)$ serum vitamin $E$ levels in adrenaline treated rats. However, no significant difference was noted between the effect of enalapril and valsartan on serum AST, plasma MDA, erythrocyte GSH and serum vitamin E levels. It may be concluded that both enalapril and valsartan offered cardioprotection in adrenaline induced oxidative stress, but the protection afforded by valsartan was not superior to enalapril.
\end{abstract}

\section{Introduction}

Myocardial infarction (MI) results from the prolonged myocardial ischemia with necrosis of myocytes due to interruption of blood supply to an area of heart ${ }^{1}$. The metabolic disarrangements that occur during ischemia predisposes for the formation of free radicals ${ }^{2}$. So, oxidative/antioxidative balance is disturbed early during the ischemic phase of acute myocardial ischemia (AMI). MI is associated with accumulation of reactive oxygen metabolites, which may play an important role in the pathogenesis of post ischemic dysfunction ${ }^{3}$. ROS are capable of reacting with unsaturated lipids and of initiating the self-perpetuating chain reactions of lipid peroxidation in the membranes. Malondialdehyde is a known stable product of lipid peroxidation ${ }^{4}$. Lipid peroxidation is thought to be involved in various pathological conditions, such as, platelet activation ${ }^{5}$, tissue destruction ${ }^{6}$. Since acute MI may be related to a thromboembolic process ${ }^{7}$, to destruction of tissue, so, a raised MDA concentration in the serum is expected $\mathbf{6}^{6}$.
Antioxidant status is an important marker of oxidative stress and may predict cardiovascular complications. GSH plays an essential protective role against oxygen reactive species. It detoxifies oxygen radicals and therefore prevents cellular damage from oxidative stress ${ }^{\mathbf{8}}$. So, it may be considered a sensitive and specific index of myocardial oxidative stress. Vitamin E, present in cellular and sub cellular membranes, provides a defense against peroxidation of vital phospholipids. So, the biochemical actions of vitamin E, are concerned with the prevention of peroxidative damage to cells and sub cellular elements'.

The activity of the adrenergic system is increased in AMI which is reflected by raised plasma catecholamine concentration $^{\mathbf{1 0}}$. A renin-angiotensin system (RAS) is present in the heart ${ }^{\mathbf{1 1 , 1 2}}$, activation of the RAS in myocardial ischemia, leads to increased formation of local Ang $\mathrm{II}^{\mathbf{1 3}}$. Reactive oxygen species (ROS) are formed in excessive amounts and are considered important to myocardial reperfusion injury ${ }^{14}$. The levels of 
angiotensin II in cardiac tissue are several times the levels of angiotensin II in circulating blood. Recent evidence suggests that most of the angiotensin II in the heart is not derived from angiotensin $I$ in the circulation, and that most of the angiotensin $I$ in cardiac tissue is generated in the tissue itself ${ }^{\mathbf{1 5}}$. Angiotensin II (Ang II) has been shown to exert a direct vasoconstrictor effects on the coronary $\operatorname{arteries}^{\mathbf{1 6}}$ and also has a direct positive chronotropic and ionotropic effect on myocardium ${ }^{\mathbf{1 7}}$. It is also regarded as a pro-oxidant because it can stimulate the production of ROS. Therefore, blockade of renin angiotensin system (RAS) by angiotensin converting enzyme inhibitor (ACEI) and angiotensin receptor blocker (ARB) could reduce oxidative stress and could be beneficial for prevention of MI. Ang I may be converted to Ang II by endothelial or extra endothelial ACE, or by chymostatin sensitive Ang II generating pathway ${ }^{\mathbf{1 8}}$. ACE inhibitors may not totally block the vascular formation of Ang II. As Ang II receptor antagonist acts more distally by blocking the $\mathrm{AT}_{1}$ receptor, so it might exert a better effect. Enalapril maleate, a class of ACE inhibitor, is inactive and becomes active enalaprilic acid when it is absorbed and deesterified in the liver. It is a potent ACE inhibitor, with a long duration of action ${ }^{\mathbf{1 9}}$. Valsartan is a new potent and specific Ang II receptor blocker $(\mathrm{ARB})^{\mathbf{2 0}}$. Among the ARBs, valsartan has 30,000 times higher affinity for $\mathrm{AT}_{1}$ than for Ang II-type 2 receptors- $\mathrm{AT}_{2}$, that selectively inhibits the biological effect of Ang II at the $\mathrm{AT}_{1}$ receptor ${ }^{21}$. Pre-treatment with this drug may reduce ROS generation. Therefore, the present study aims at deciding whether enalapril or valsartan, which one is the definitive winner to prevent oxidative stress in MI.

\section{Materials and Methods}

Drugs: Adrenaline, ampoule containing $1 \mathrm{mg} / \mathrm{ml}$ (1:1000) - (GacoBangladesh) was purchased from local market. Enalapril Maleate was provided by Beximco Pharmaceuticals and Valsartan by Orion Pharmaceuticals as gifts.

Animals: The experiment was carried out on 36 healthy rats of Long Evans Norwegian strain, aged between 2-3 months of both sexes, weighing between 170-210 gm, fed on standard rat diet and allowed to drink water ad libitum.

Experimental design: Experimental animals were divided into six groups each group containing six rats and were treated accordingly. Group I received distilled water $(1 \mathrm{ml})$ subcutaneously daily in a single dose 24 hours apart for 2 consecutive days and served as control. Group II received only enalapril through intragastric tube for 14 days; group III received only valsartan through intragastric tube for 14 consecutive days. Group IV received adrenaline $(2 \mathrm{mg} / \mathrm{kg} \text { body weight })^{\mathbf{2 2}}$ subcutaneously daily in a single dose 24 hours apart for 2 consecutive days. Group $\mathrm{V}$ received enalapril $(30 \mathrm{mg} / \mathrm{kg} \mathrm{bw})^{\mathbf{2 3}}$ orally through intragastric tube daily for 14 consecutive days, then adrenaline was given subcutaneously in a single dose 24 hours apart for 2 consecutive days from $15^{\text {th }}$ day. Group VI was treated with valsartan $(30 \mathrm{mg} / \mathrm{kg} \mathrm{bw})^{\mathbf{2 4}}$, daily orally through intragastric tube for 14 days, on $15^{\text {th }}$ day $1^{\text {st }}$ injection of adrenaline and after 24 hours the $2^{\text {nd }}$ injection were given. All the rats were sacrificed 24 hours after the last dose under light anesthesia by chloroform. About $2 \mathrm{ml}$ of blood from each rat was collected in a clean and dry test tube by cervical decapitation. The serum was separated by ultra-centrifugation $(4000 \mathrm{rpm}$ for 5 minutes) and collected by micropipette, transferred to labeled test tubes for biochemical study.

\section{Methods for studying bio-chemical parameters:}

Estimation of Serum AST levels: Serum AST levels was estimated by kinetic test UV-optimized IFCC method (J. Clin. Chem. ClinBiochem 1986; 24:497). The concentration of enzyme was measured in spectrophotometer (Micro Flow Cell Photometer AE-100F ERMA Inc) at wavelength $340 \mathrm{~nm}$.

Estimation of GSH concentration in erythrocyte: GSH concentration in erythrocyte was estimated by Ellman's method ${ }^{25}$. The color intensity was measured by the spectrophotometer (UV-VIS spectrophotometer) at $412 \mathrm{~nm}$ wavelength.

Estimation of Plasma MDA level: Plasma MDA level was estimated by Thiobarbituric acid $\operatorname{method}^{\mathbf{2 6}}$. The absorbance was measured using spectrophotometer at $532 \mathrm{~nm}$.

Estimation of Serum vitamin E level: Serum vitamin $\mathrm{E}$ level was estimated by colorimetric $\operatorname{method}^{27}$. Tocopherols and carotenes are first extracted into xylene and the absorbance is read at $460 \mathrm{~nm}$ to measure the carotenes. A correction for the carotenes is made after adding ferric chloride and reading at $520 \mathrm{~nm}$.

The quantitative variables were expressed as mean \pm SD. ANOVA (multiple comparisons) was done for statistical analysis. Post hoc analyses of differences were done by Bonferroni test.

\section{Result}

Results showed that administration of enalapril or valsartan did not cause any significant change in serum AST, plasma MDA, erythrocyte GSH and 
serum vitamin E levels when compared with control (Table I).

Serum AST level in the adrenaline-treated rats and control group were 116.86 $\pm 21.49 \mathrm{U} / \mathrm{L}$ and $25.46 \pm 3.51 \mathrm{U} / \mathrm{L}$ respectively. The rise in serum AST level was significant $(\mathrm{p}<0.001)$. Twenty four hours after the 2 nd injection of adrenaline, serum AST level in enalapril and valsartan pre-treated group was 57.6 $\pm 6.88 \mathrm{U} / \mathrm{L}$ and 54.82 $\pm 8.08 \mathrm{U} / \mathrm{L}$ respectively. The decrease in serum AST level in both the pre-treated group as compared to only adrenaline treated group was significant $(\mathrm{p}<0.001)$ (Table I). Enalapril and valsartan pre-treatment decreased the serum AST level by $50.71 \%$ and $53.09 \%$ respectively (Table II).

Twenty four hours after the 2nd injection of adrenaline, plasma MDA level in the adrenaline treated rats and control group were 1.22 \pm 0.12 $\mu \mathrm{mol} / \mathrm{L}$ and $0.39 \pm 0.09 \mu \mathrm{mol} / \mathrm{L}$ respectively. The rise in the plasma MDA level was significant $(\mathrm{p}<0.001)$. Plasma MDA level in enalapril pretreated group was $0.74 \pm 0.12$ and in valsartan pretreated group was $0.91 \pm 0.08 \mu \mathrm{mol} / \mathrm{L}$ after the $2 \mathrm{nd}$ injection of adrenaline. In the pre-treated groups, the decrease in plasma MDA level as compared to only adrenaline treated group was significant $(\mathrm{p}<0.001)$ (Table I). Pre-treatment with enalapril and valsartan reduced plasma MDA level by $39.34 \%$ and $25.41 \%$ respectively (Table II).

The concentration of erythrocyte GSH in adrenaline treated group and control group were $0.57 \pm 0.17 \mathrm{mg} / \mathrm{gmHb}$ and $1.26 \pm 0.13 \mathrm{mg} / \mathrm{gmHb} 24$ hours after the 2nd injection of adrenaline respectively. The reduction in concentration of erythrocyte GSH concentration was significant $(p<0.001)$. After the 2nd injection of adrenaline, the concentration of erythrocyte GSH in enalapril and valsartan pre-treated groups were 1.09 \pm 0.26 and $0.98 \pm 0.14 \mathrm{mg} / \mathrm{gmHb}$ respectively. The change in the concentration of erythrocyte GSH in enalapril pre-treated group $(\mathrm{p}<0.01)$ and in valsartan pre-treated group $(\mathrm{p}<0.05)$ (Table I) as compared to only adrenaline treated group was significant. Enalapril pre-treatment increased $42.11 \%$ and valsartan pre-treatment increased $40.35 \%$ erythrocyte GSH concentration in adrenaline treated rats (Table II).

Serum vitamin E level in the adrenaline-treated rats and in the control group 24 hours after the 2nd injection of adrenaline were $6.20 \pm 1.33 \mathrm{mg} / \mathrm{L}$ and $11.22 \pm 0.96 \mathrm{mg} / \mathrm{L}$ respectively. The decrease in the serum vitamin $\mathrm{E}$ level was significant $(\mathrm{p}<0.001)$. Serum vitamin E level in enalapril pretreated group was $9.27 \pm 0.9 \mathrm{mg} / \mathrm{L}$ and in valsartan pre-treated group was $8.95 \pm 1.27 \mathrm{mg} / \mathrm{L}$ after the $2 \mathrm{nd}$ injection of adrenaline. The attenuation in serum vitamin E levels by enalapril and valsartan pretreatment as compared to only adrenaline treated group was significant $(\mathrm{p}<0.01)$ (Table I). Treatment with enalapril and valsartan increased serum vitamin E level by $49.52 \%$ and $44.34 \%$ respectively (Table II).

The change in serum AST level when compared between enalapril and valsartan pre-treated groups, the change was not significant $(p>0.05)$. Also the changes in plasma MDA, erythrocyte GSH and serum vitamin $\mathrm{E}$ levels in enalapril and valsartan pre-treated groups when compared with each other, they were not significant $(\mathrm{p}>0.05)$ (Table II).

Plasma MDA to serum vitamin E ratio (Plasma MDA/serum vitamin E) is calculated. The unit of serum vitamin $\mathrm{E}$ is converted to $\mu \mathrm{mol} / \mathrm{L}$ from $\mathrm{mg} / \mathrm{L}$ (Table III).

Table I: Serum AST, plasma MDA, erythrocyte GSH and serum vitamin $\mathrm{E}$ levels after adrenaline administration in enalapril and valsartan pre-treated rats

\begin{tabular}{|c|c|c|c|c|}
\hline Groups & $\begin{array}{c}\text { Serum AST } \\
(\mathrm{U} / \mathrm{L}) \\
(\text { Mean } \pm \mathrm{SD})\end{array}$ & $\begin{array}{c}\text { Plasma } \\
\text { MDA }(\mu \mathrm{mol} / \mathrm{L}) \\
(\text { Mean } \pm \mathrm{SD})\end{array}$ & $\begin{array}{c}\text { Erythrocyte GSH } \\
\text { (mg/gmHb) } \\
\text { (Mean } \pm \text { SD) }\end{array}$ & $\begin{array}{c}\text { Serum vitamin } \\
E(m g / l) \\
(M e a n \pm S D)\end{array}$ \\
\hline $\begin{array}{l}\text { Control (DW) } 1 \mathrm{ml} \\
(\mathrm{Gr}-\mathrm{I})\end{array}$ & $25.46 \pm 3.51$ & $0.39 \pm 0.09$ & $1.26 \pm 0.13$ & $11.22 \pm 0.96$ \\
\hline $\begin{array}{l}\text { Enalapril 30mg/kg bw } \\
(\mathrm{Gr}-\mathrm{II})\end{array}$ & $34.03 \pm 4.03 \mathrm{a}_{0}$ & $0.38 \pm 0.09 a_{0}$ & $1.26 \pm 0.14 \mathrm{a}_{0}$ & $12.46 \pm 1.32^{a_{0}}$ \\
\hline $\begin{array}{l}\text { Valsartan 30mg/kg bw } \\
(\mathrm{Gr}-\mathrm{III})\end{array}$ & $35.77 \pm 9.21^{b} 0$ & $0.42 \pm 0.08^{\mathrm{b}} 0$ & $1.24 \pm 0.21^{\mathrm{b}} 0$ & $11.87 \pm 1.61^{b} b_{0}$ \\
\hline $\begin{array}{l}\text { Adrenaline } 2 \mathrm{mg} / \mathrm{kg} \text { bw } \\
(\mathrm{Gr}-\mathrm{IV})\end{array}$ & $116.86 \pm 21.49 c_{3}$ & $1.22 \pm 0.12^{c_{3}}$ & $0.57 \pm 0.17 c_{3}$ & $6.20 \pm 1.33 c_{3}$ \\
\hline $\begin{array}{l}\text { Enalapril } 30 \mathrm{mg} / \mathrm{kg} \text { bw } \\
+\mathrm{Inj} \text {. Adrenaline } \\
2 \mathrm{mg} / \mathrm{kg} \text { bw }(\mathrm{Gr}-\mathrm{V})\end{array}$ & $57.6 \pm 6.88 d_{3}$ & $0.74 \pm 0.12^{d_{3}}$ & $1.09 \pm 0.26 d_{2}$ & $9.27 \pm 0.9 d_{2}$ \\
\hline $\begin{array}{l}\text { Valsartan } 30 \mathrm{mg} / \mathrm{kg} \text { bw } \\
+ \text { Inj. Adrenaline } 2 \\
\mathrm{mg} / \mathrm{kg} \text { bw (Gr-VI) }\end{array}$ & $54.82 \pm 8.08 e_{3}$ & $0.91 \pm 0.08 e_{3}$ & $0.98 \pm 0.14 \mathrm{e}_{1}$ & $8.95 \pm 1.27 \mathrm{e}_{2}$ \\
\hline
\end{tabular}

Values were expressed as mean $\pm \mathrm{SD}$ $a_{0} p>0.05$ Gr II versus Gr I $\quad d_{3} p<0.001$ Gr IV versus Gr V $b_{0} p>0.05$ Gr III versus Gr I $\quad e_{1} p<0.05$ Gr IV versus Gr VI $c_{3} p<0.001$ Gr IV versus Gr I $\quad e_{2} p<0.01$ Gr IV versus Gr VI $\mathrm{d}_{2} \mathrm{p}<0.01 \mathrm{Gr}$ IV versus Gr V $\quad \mathrm{e}_{3} \mathrm{p}<0.001$ Gr IVversus Gr VI

Table II: Intergroup variation with percentage of increase or decrease

\begin{tabular}{|c|c|c|c|}
\hline Variable & $\begin{array}{c}\text { Enalapril+Adr } \\
\text { enaline } \\
(\mathrm{Gr}-\mathrm{V}) \\
\end{array}$ & $\begin{array}{c}\text { Valsartan+A } \\
\text { dranaline } \\
(\mathrm{Gr}-\mathrm{VI}) \\
\end{array}$ & $\begin{array}{c}\text { Level of } \\
\text { Significance }\end{array}$ \\
\hline Serum AST & $50.71 \% \downarrow$ & $53.09 \% \downarrow$ & $1.000^{\mathrm{NS}}$ \\
\hline Plasma MDA & $39.34 \% \downarrow$ & $25.41 \% \downarrow$ & $0.150^{\mathrm{NS}}$ \\
\hline Erythrocyte GSH & $42.11 \% \uparrow$ & $40.35 \% \uparrow$ & $1.000^{\mathrm{NS}}$ \\
\hline Serum vitamin $\mathrm{E}$ & $49.52 \% \uparrow$ & $44.34 \% \uparrow$ & $1.000^{\mathrm{NS}}$ \\
\hline
\end{tabular}

Table III: Ratio of plasma MDA to serum vitamin E

\begin{tabular}{llc}
\hline \multicolumn{1}{c}{ Variable } & $\begin{array}{c}\text { (Enalapril }+ \\
\text { Adrenaline) } \\
\text { Group V }\end{array}$ & $\begin{array}{c}\text { (Valsartan }+ \\
\text { Adrenaline) } \\
\text { Group VI }\end{array}$ \\
\hline $\begin{array}{l}\text { Plasma MDA/serum vitamin E ratio } \\
(\mu \text { mol per liter/ } \mu \text { mol per liter })\end{array}$ & 0.019 & 0.024
\end{tabular}




\section{Discussion}

Reactive oxygen species (ROS) generation during AMI are known to play a major role in causing necrosis of myocardial tissue and Ang II contributes in part to ROS production in heart via Ang II type $1\left(\mathrm{AT}_{1}\right)$ receptor mediated induction of NADPH oxidase which might result in myocardial damage by increasing oxidative stress ${ }^{28}$. This was known earlier that antioxidants and some cardioprotective drugs that eliminate pro-oxidants and scavange free radicals may provide protection against ischemic myocardial damage ${ }^{29}$. Ang II receptor blockers (ARBs) and ACE inhibitors can inhibit the source of ROS in the heart. Thus these agents may represent casual antioxidants that eliminate injurious oxidative stress in the heart. The aim of the present study is to evaluate and compare the protective effect of $\mathrm{AT}_{1}$ receptor blocker and ACE inhibitor in adrenaline induced oxidative stress in experimental MI in rats. The results of this study showed that pretreatment of valsartan (30 $\mathrm{mg} / \mathrm{kg}$ ) or enalapril $(30 \mathrm{mg} / \mathrm{kg}$ ) for 2 weeks before administration of adrenaline $(2 \mathrm{mg} / \mathrm{kg}$ in two subsequent doses, 24 hours apart) afforded cardioprotection as evidenced by significant reduction in serum AST level and markers of oxidative stress.

In this investigation, significant rise in serum AST level was found after 24 hours of adrenaline treatment. AST starts to rise about 12 hours after infarction and reaches a peak on the $1^{\text {st }}$ or $2^{\text {nd }} \mathrm{day}^{30}$. The sera of rats with myocardial necrosis were worthy of particular attention because of the possibility that destruction of cardiac muscle, rich in transaminase activity, results in a release of this enzyme into blood stream and thus increase the serum transaminase activity. An increase in oxidative stress after adrenaline treatment was revealed by a significant increase in plasma MDA level and a significant decrease in erythrocyte GSH concentration and serum vitamin $\mathrm{E}$ level. The rise in MDA level indicates enhanced lipid peroxidation which is one of the important manifestations of oxidative damage initiated by $\operatorname{ROS}^{31}$. Couple of researchers $^{31}$, in their study showed that myocardial injury induced in rats with Isoproterenol for 2 days resulted in a marked elevation of lipid peroxidation, serum marker enzymes and a significant decrease in activities of endogenous antioxidants such as reduced GSH. Some others ${ }^{32}$ demonstrated increased concentration of plasma MDA and decreased level of plasma GSH and vit E in AMI patients at the time of admittance to the hospital. Similarly significant rise in erythrocyte MDA level and significant fall in GSH level were observed in MI patients by some researchers. Our results indicate that adrenaline has got the ability to produce ROS which enhance lipid peroxidation, a detoriative process in myocardial cells that results in the increase in serum AST levels. Oxygen derived free radicals are generated particularly in the early stage of MI and GSH is involved in the reduction of hydrogen peroxide radicals, resulting in a decrease in GSH levels during that period ${ }^{33}$. Prolonged exposure to oxidative stress (as seen in $\mathrm{MI}$ ), was found to result in depletion of the defense system which might decrease GSH activity ${ }^{34}$. The antioxidant vitamin $\mathrm{E}$ was found to be decreased in plasma of AMI patients in previous studies ${ }^{35,36}$. The finding of the present study correlates with those studies. The antioxidant vitamin E interrupts lipid peroxidation by scavenging peroxyl radical intermediately ${ }^{37}$. The decreased erythrocyte GSH and plasma vitamin E level may be associated with enhanced protective mechanism to oxidative stress in MI patients.

Ang II is regarded as a pro-oxidant because it induces $\mathrm{O}_{2}{ }^{-}$release via activation of membrane bound NADPH-oxidases ${ }^{38}$. A number of studies documented that ARBs have antioxidant properties most likely due to modulation of NADPH oxidase activity $^{39}$. In our study pre-treatment with enalapril or valsartan caused significant decrease in the erythrocyte MDA level 24 hours after adrenaline administration. In a study by some researchers ${ }^{40}$, it was seen that enalapril significantly decreased the level of plasma MDA in atherosclerotic rabbit compared to the control group. They explained that enalapril a nonsulfhydryl containing ACE inhibitor, reduces MDA level by inhibiting lipid peroxidation. Another group ${ }^{41}$ investigated the vascular effects of ARB in hypertensive patients and found that compared with control, ARB significantly reduced plasma MDA level. Couple of researchers ${ }^{42}$ examined the effect of $\mathrm{AT}_{1}$ receptor blocker on atherosclerosis and found that MDA was reduced compared to control. Inhibition of lipid peroxidative effect in this study caused by enalapril and valsartan was $39.34 \%$ and $25.41 \%$ respectively. However, difference in antiperoxidative effect was not significant when compared between these two drugs. In this investigation, enalapril or valsartan pre-treatment for 14 days significantly increased erythrocyte GSH concentration and plasma vitamin E level in adrenaline treated rats. The effects of enalapril and valsartan on erythrocyte GSH level were $42.11 \%$ and $40.35 \%$ respectively and this difference was not significant. On the other hand, the effects of enalapril and valsartan on plasma vitamin $E$ level were $49.52 \%$ and $44.34 \%$ respectively and the difference was not significant. Another group of researchers ${ }^{43}$ investigated glutathione content of 
various tissues and reported that enalapril administration was able to enhance total glutathione content in various tissues including erythrocytes. On the other hand, some others examined the changes in oxidative stress parameters by blocking the RAS at $\mathrm{AT}_{2}$ receptor site and found that ARB significantly increased GSH and CAT activity and oxidative stress was markedly reduced. They concluded that ARB appears to modulate free radical production, increase antioxidants and reduce oxidative stress. In our study enalapril and valsartan pretreatment significantly increased plasma vitamin E level in adrenaline treated rats. The plasma MDA to serum vitamin $\mathrm{E}$ ratio was calculated and the ratio was found to be low and it indicates amelioration of oxidative stress in enalapril or valsartan pretreated groups. The possible mechanism of reduction of oxidative stress could be that both of these drugs act by inhibiting RAS pathway and resulting in a decrease in the activity of Ang II. Ang II is recognized to be one of the major contributors to the progression of heart disease through generation of ROS. By inhibiting this pathway these two drugs reduce ROS generation which ultimately raises the endogenous antioxidant vitamin $\mathrm{E}$.

It may be concluded that ACE inhibitor and angiotensin II receptor blocker (ARB) both can afford cardioprotection by reducing oxidative stress as evidenced by a decrease in plasma MDA level, an increase in erythrocyte GSH concentration and serum vitamin $\mathrm{E}$ level and low MDA to vitamin $\mathrm{E}$ ratio. However, cardioprotective effect of ARB is not superior to ACE inhibitor.

\section{References}

1. Whellan DJ. Heart failure disease management: implementation and outcomes. Cardiol Rev. 2005; 13: 231-39.

2. Ferrari R, Ceconi C, Curello S, Cargnoni A, Pasini E, Giuli FD, et al. Role of Oxygen Free Radicals in Ischemic and Reperfusion Myocardium. Am J ClinNutr. 1991; 53: 215-22.

3. Myers ME, Bolli R, Lekich RF, Hartley CJ, Roberts R. Enhancement of recovery of myocardial function by oxygen free-radical scavengers after reversible regional ischemia. Circulation 1985; 72: 915-21.

4. Placer ZA, Cushman LL, JohnsonBC. Estimation of product of lipid peroxidation (Malondialdehyde) in biochemical systems. Anal Biochem 1966; 16: 359-64.

5. Smith JB, Ingerman CM, Silver MJ. Malondialdehyde formation as an indicator of prostaglandin production by human platelets. J Lab Clin Med1976; 88(1): 67-72.

6. Aznar J, Santos MT, Valles J, Sala J. Serum malondialdehyde-like material (MDA-LM) in acute myocardial infarction. J Clin Pathol. 1983; 36: 712-15.
7. Harker LA and Ritchie JL. The role of platelets in acute vascular events. Circulation. 1980; 62: 13-8.

8. Stamler JS, Sliyka A. Biological chemistry of thiols in the vasculature and vascular-related disease. Nutr Rev. 1996; 54: 1-30

9. Ellis NI, Lloyd B, Lloyd RS, Clayton BE. Selenium and vitamin $\mathrm{E}$ in relation to risk factors for coronary heart disease. J Clin Pathol. 1984; 37: 200-6.

10. Januszewicz W, Sznajderman M, Sznajderman C, Wocial B, Rymaszewski Z. Plasma free fatty acid and catecholamine levels in patients with acute myocardial infarction. Brit Heart J. 1971; 33: 716-8.

11. Dostal DE, Baker KM. The cardiac renin-angiotensin system : conceptual, or a regular of cardiac function? Circ Res. 1999; 85: 643-50.

12. Bader M, Peters J, Baltatu O, Muller DN, Luft FC, Gauten D. Tissue renin-angiotensin systems: new insights from experimental animal models in hypertension research. J Mol Med (Berl) 2001; 79: 76102.

13. Jalowy A, Schulz R, Heusch G. AT1 receptor blockade in experimental myocardial ischemia/reperfusion. J Am Soc Nephrol. 1999; 10: 129-36.

14. Zweier JL. Measurement of superoxide-derived free radicals in the reperfused heart. Evidence for a free radical mechanism of reperfusion injury. $\mathrm{J}$ Biol Chem. 1988; 263: 1353-7.

15. Danser AHJ, Schalekamp MADH. Is there an internal cardiac renin-angiotensin system? Heart 1996; 76: 2832.

16. Sudhir K, MacGregor JS, Gupta M, Barbant SD, Redberg R. Effect of selective angiotensin II receptor antagonism and angiotensin converting enzyme inhibition on the coronary vasculature in vivo. Intravascular two-dimensional and doppler ultrasound studies. Circulation. 1993; 87: 931-38.

17. Michel JB, Lattion AL, Salzmann JL, Cerol ML, Philippe M, Camilleri JP, et al. Hormonal and cardiac effects of converting enzyme inhibition in rat myocardial infarction. Circ Res. 1988; 62: 641-50.

18. Okunishi H, Miyazaki M, Toda N. Evidence for a putatively new angiotensin II-generating enzyme in the vascular wall. J Hypertens 1984; 2: 277-84.

19. Ulm EH. Enalapril Maleate (MK-421), a potent, nonsulfhydryl angiotensin-converting enzyme inhibitor: absorption, disposition, and metabolism in man. Drug Metab Rev. 1983; 14: 99-110.

20. Criscione L, Bradley WA, Buhlmayer P, Whitebread S, Glazer R, Lloyd P, et al. Valsartan: Preclinical and clinical profile of an antihypertensive angiotensin-II antagonist. Cardiovasc Drug Rev. 1995; 13: 230-50.

21. Gasparo M. New basic science initiatives with the angiotensin II receptor blocker valsartan. JRAAS. 2000; $1: 3-5$. 
22. Khan I. Effect of antioxidant vitamins $\mathrm{E}$ and $\mathrm{C}$ on adrenaline induced myocardial damage in rats. Dissertation: University of Dhaka; 1996.

23. Leary SC, Michaud D, Lyons CN, Hale TM, Bushfield TL, Adams MA, et al. Bioenergetic remodeling of heart during treatment of spontaneously hypertensives rats with enalapril. Am J Physiol Heart Circ Physiol. 2002; 283: 540-8.

24. Yu Cm, Tipoe GL, Wing-Hon LK, Lau CP. Effects of combination of angiotensin-converting enzyme inhibitor and angiotensin receptor antagonist on inflammatory cellular infiltration and myocardial interstitial fibrosis after acute myocardial infarction. J Am Coll Cardiol. 2001; 38(4): 1207-15.

25. Ates NA, Yildirim O, Tamer L, Unlu A, Ercan B, Muslu N, et al. Plasma catalase activity and malondialdehyde level in patients with cataract. Eye. 2004; 18: 785-8.

26. Baker H, Frank O. Determination in serum tocopherol. Practical clinical biochemistry. $6^{\text {th }}$ ed. London: Heinemenn Medical Books, 1968

27. Matsuhisa S, Otani H, Okazaki T, Yamashita K, Akita $\mathrm{Y}$, Sato D, et al. Angiotensin II type 1 receptor blocker preserves tolerance to ischemia-reperfusion injury in Dahl salt-sensitive rat heart. Am J Physiol Heart Circ Physiol. 2008; 294: 2473-9.

28. Bandyopadhyay D, Chattopadhyay A, Ghosh G, Datta AG. Oxidative Stress Induced Ischemic Heart Disease: Protection by Antioxidants. Current Medicinal Chemistry. 2004; 11: 369-87.

29. Boon NA, Fox KAA, Bloomfield P. Disease of cardiovascular system. Davidson's Principles and Practice of Medicine. 18th ed. Edinberg: Churchill Livingstone, 1999.

30. Yogeeta SK, Gnanapragasam A, Kumar SS, Subhashini R, Sathivel A, Devaki T. Synergistic interactions of ferulic acid with ascorbic acid: Its cardioprotective role during isoproterenol induced myocardial infarction in rats. Mol Cell Biochem. 2006; 283: $139-46$.

31. Simic D, Oka JM, Pljesa M, Milanovic D, Radojevic S, Ivanovic B, et al. Time course of erythrocyte antioxidant activity in patients treated by thrombolysis for acute myocardial infarction. Jpn Heart J. 2003; 44: 823-32.

32. Shimizu H, Kiyohara Y, Kato I, Kitazono T, Tanizaki Y, Kubo M, et al. Relationship between plasma glutathione levels and cardiovascular disease in a defined population: The hisayama study. Stroke. 2004; 35: 2072-7.
33. Li RK, Sole MJ, Mickle DAG, Schimmer J, Goldstein D. Vitamin E and oxidative stress in the heart of the cardiomyopathic syrian hamster. Free Rad Biol Med 1998; 24: 252-8.

34. Jayakumari N, Ambikakumari V, Balakrishnan KG, Iyer KS. Antioxidant status in relation to free radical production during stable and unstable angina syndromes. Atherosclerosis. 1992; 94(2-3): 183-90.

35. Scragg R, Jackson R, Holdaway I, Woollard G, Woollard D. Changes in plasma vitamin levels in the first 48 hours after onset of acute myocardial infarction. Am J cardiol 1989; 64(16): 971-4.

36. Burton $\mathrm{GW}$, Ingold $\mathrm{KU}$. Vitamin $\mathrm{E}$ as an in vitro and in vivo antioxidant. Ann N Y Acad Sci 1989; 570: 7 22.

37. Dandona P, Kumar V, Aljada A, Ghanim H, Syed T, Hofmayer D, et al. Angiotansin II receptor blocker suppresses reactive oxygen species generation in leukocytes, nuclear.

38. Schiffrin EL, Touyz RM. From bedside to bench to bedside: role of renin-angiotensin-aldosterone system in remodeling of resistance arteries in hypertension. Am L Physiol Heart Circ Physiol 2004; 287: 435-46.

39. Khalifa MMA, Hassan MKA, AshourOM, Haleem ABTAA. Lipid peroxidation and atherosclerosis: effect of calcium channel blockers and angiotensin converting enzyme inhibitors. J Egypt Soc Toxicol 1999; $21: 1-8$

40. Koh KK, Ahn JY, Han SH, Kim DS, Jin DK, Kim HS, et al. Pleitropic effects of angiotensin II receptor blocker in hypertensive patients. J Am Coll Cardiol 2003; 42(5): 905-10.

41. Takaya T, Kawashima S, Shinohara M, Yamashita T, Toh R, Sasaki N, et al. Angiotensin II type 1 receptor blocker telmisartan suppresses superoxide production and reduces atherosclerotic lesion formation in apolipoprotein E-deficient mice. Atherosclerosis 2006; 186(2): 402-10

42. Cavanagh EMV, Inserra F, Ferder L, Fraga CG Enalapril and Captopril enhance glutathione-dependent antioxidant defenses in mouse tissues. Am J Physiol Regulatory Integrative Comp Physiol 2000; 278: 572-7.

43. Khaper N, Singal PK. Modulation of oxidative stress by a selective inhibition of angiotensin II type 1 receptors in MI rats. J Am Coll Cardiol 2001; 37: 1461-6. 